\title{
OKOLNOSTI VZNIKU SVAZU ČESKÝCH SKLADATELŮ A KONCERTNÍCH UMĚLCŮ A JEHO BRNĚNSKÉ POBOČKY
}

Tímto př́spěvkem si Vás dovolím krátce seznámit s problematikou vzniku Svazu českých skladatelů a koncertních umělců, především jeho krajské organizace v Brně. Nejprve stručně nastíním vývoj v roce 1969 na úrovni celonárodního a již pomalu zanikajícího Svazu československých skladatelů, poté se budu zabývat mezidobím prípravného procesu a přechodu $\mathrm{k}$ Svazu novému, se zvláštním zřetelem k brněnské pobočce Svazu. Ke svému př́spěvku jsem využila nemnohé literatury, která se k tomuto období a předmětu nachází, jde spíše o stručné pasáže v monografích věnovaných brněnským skladatelům - např. Josefu Bergovi, Miloslavu Ištvanovi, Janu Kaprovi. Dále pak jsem vyhledala dobové zprávy v českých hudebních periodicích, především v Hudebních rozhledech a časopisu Opus musicum. Nápomocnou mi také byla diplomová magisterská práce kolegy Jana Karafiáta z roku 2011. V největší míře však čerpám z archivu brněnské pobočky Svazu českých skladatelů a koncertních umělcủ, který je uložen v Oddělení dějin hudby Moravského zemského muzea. Tímto archivem se již delší dobu zabývám, jednak pro spolupráci na projektu Dokumentace k české hudební kultuře, jednak pro svou dizertační práci, kterou chci věnovat právě brněnské pobočce Svazu českých skladatelů a koncertních umělců, její historii a činnosti. Některé informace z brněnského prostředí jsou proto poněkud kusé, protože se mi ne vždy podařilo dohledat př́slušné materiály $\mathrm{v}$ archivu pobočky. Tento archiv zatím zůstává nezpracovaný.

Svaz českých skladatelů a koncertních umělců je název pro organizaci, která nahradila dřívější Svaz československých skladatelů, fungující v letech 1949 až 1969. V následujícím období 1970 až 1989 byl Svaz českých skladatelů a koncertních umělců jedinou oficiální organizací sdružující profesionální skladatele, koncertní umělce, hudební publicisty a muzikology. V rámci tehdejší kulturní politiky byl svaz definován jako dobrovolná, výběrová, ideově-tvưrčí organizace pracovníků těchto profesí. Měl za úkol pečovat o ideový a tvůrčí růst svých členů a vytvářet podmínky pro uplatnění jejich tvorby. ${ }^{1}$

1 Slovník české hudební kultury (Praha, 1997). 
Ukončení činnosti Svazu československých skladatelů a vznik Svazu nového byly motivovány politicky. Obrat $\mathrm{v}$ politice a v následných krocích nového vedení Komunistické strany Československa ke konsolidaci společnosti po roce 1968 znamenal i obrat ve fungování Svazu. Ještě na Mimořádném sjezdu Svazu československých skladatelů dne 26. února $1969,{ }^{2}$ jehož hlavním námětem byla kulturněpolitická situace v zemi a postoj umělců v ní, se členové postavili za udržení reformní politiky jak pro umění, tak pro celou společnost. Avšak na posledním zasedání Ústředního výboru Svazu československých skladatelů, které se konalo 20. listopadu 1969 a kde se jednalo o tehdejší situaci Svazu a jeho dalším směřování, již bylo zřejmé, že bude nutné rozejít se s těmito názory a náležitě se od těchto postojů distancovat. Jak události pokračovaly, je patrné z ustanovení, které Ústřední výbor na tomto jednání přijal a z něhož citujeme:

„Valné shromážděni Svazu českých skladateli̊ přijalo na svém zasedáni dne 26. února 1969 některé závěry, ${ }^{3}$ které se postupně dostávaly do stále většího rozporu se základními tendencemi politického vývoje u nás. Plněni těchto závěrủ by neodpovídalo současné politice KSČ, vlády a Národni fronty. Vzhledem $k$ tomu, že ÚV SČS neni oprávnèn měnit závěry valného shromáždèní, usoudil na svém zasedáni 20. 11. 1969, že je třeba $k$ vyjasněni a vyřšeneni těchto problémů svolat nové valné shromážděni Svazu českých skladatelì. "“

Po přijetí tohoto usnesení abdikovala většina členů ze svých funkcí v Ústředním výboru svazu. ${ }^{5}$ Zbývající členové, čtyři z Ústředního výboru - Čestmír Gregor, Josef Chuchro, Josef Páleníček a Karel Pravoslav Sádlo, čtyři z Kontrolní a revizní komise - Pavel Čotek, Milan Etlík, Štěpán Lucký a Hubert Šimáček, a vedoucí tajemník Václav Kučera zůstali ve svých funkcích a ujali se prozatímního vedení Svazu. Toto prozatímní vedení pak bylo jádrem Přípravného výboru Svazu českých skladatelů a koncertních umělců, které, po doplnění dalších členů, jmenoval v prosinci 1970 ministr kultury ČSR. Př́pravný výbor pak na své schůzi 18. prosince 1970 zvolil nové předsednictvo ve složení: Oldřich Flosman, Karel Horký, Václav Kučera, Josef Matěj, Josef Páleníček, Jiř́i Pauer, Vilém Pospíšil, Jan Tausinger a Lubomír Železný. Předsedou př́ípravného výboru byl zvolen Josef Páleníček, místopředsedy Oldřich Flosman, Karel Horký a Josef Matěj, do funkce vedoucího tajemníka Václav Kučera, vedením stranické skupiny byl pověřen Lubomír Železný. Na závěr jednání přijali Stanovisko, v němž se distancovali od dosavadní činnosti uměleckých svazů a zdůraznili svou plnou podporu novému vedení Komunistické strany Československa. ${ }^{6}$

2 Zpráva o průběhu mimořádného sjezdu Svazu čs. skladatelů. Hudební rozhledy, 1969, roč. 22 , č. 6, s. 162.

3 Memorandum ustavujícího valného shromáždění Svazu českých skladatelů. Hudební rozhle$d y, 1969$, roč. 22, č. 6, s. 163.

4 Analýza činnosti a vývojových tendencí SČS od jeho IV. sjezdu (1967) do období likvidace (1971), uloženo v ODH MZM, Archiv brněnské pobočky SČS, nečíslovaná složka. skladateli mezi 4. sjezdem a rozpadem SČS. Brno, 2011, s. 57. 
Úkoly př́ípravného výboru pak byly následující: zkonsolidovat poměry na půdě Svazu, vyvolané tzv. krizovým obdobím v letech 1968 až 1969, ukončit činnost starého Svazu československých skladatelů a konstituovat nový Svaz, který se měl distancovat od činnosti bývalého svazu a měl se hlásit k normalizační komunistické politice, získat pro členství a práci ve Svazu ty, kteří projevili souhlas se Stanoviskem ze dne 18. prosince 1970, navázat přerušené kontakty se skladatelskými svazy zemí Východního bloku a zejména připravit ustavující sjezd nového svazu.

Stanovy nového svazu ${ }^{7}$ byly schváleny Ministerstvem vnitra ČSR dne 23. prosince 1970 a na základě těchto stanov zahájil Svaz českých skladatelů a koncertních umělců oficiálně svou činnost.

Ustavující sjezd Svazu českých skladatelů a koncertních umělců se konal 19. prosince 1972. Tohoto sjezdu se zúčastnilo 101 členů svazu z celkového počtu 146, kteří zastupovali všechny hlavní zmíněné oblasti: oblast skladatelskou, oblast koncertních umělců a oblast hudebních publicistů a kritiků. Na sjezdu byly jednomyslně schváleny základní dokumenty - Analýza činnosti Svazu čs. skladatelů, Program činnosti SČSKU a rezoluce sjezdu. Výsledky jednání ustavujícího sjezdu důsledně vycházejí ze závěrů XIV. sjezdu KSČ a ideologického pléna ÚV KSČ z listopadu $1972 .^{8}$

Období bezprostředně následující po ustavujícím sjezdu Svazu českých skladatelů a koncertních umělců bylo pro brněnskou pobočku ve znamení př́prav na založení nové krajské organizace. Také v Brně byl ustaven přípravný výbor, který se zaměřil především na budování nové členské základny. V tomto směru prípravný výbor postupoval velmi obezřetně, nebot' ti umělci, jejichž jména byla spjata s událostmi roku 1968, neměli být do nového svazu vůbec přijati. Během roku 1973 se tedy prrípravnému výboru podařilo vytvořit podmínky pro vznik krajské organizace. Dne 20. záŕí 1973 byla slavnostně ustanovena na členském aktivu, ${ }^{9}$ členové se shodli na plánu práce krajské pobočky a do svého vedení zvolili pětičlenný výbor, jehož předsedou se stal Karel Horký. ${ }^{10}$ Funkci tajemníka zastával už od roku 1969 Arnošt Parsch a v této funkci setrval do roku 1977.

Po ustavení krajské organizace se práce ve svazu soustředila především na zhodnocení minulosti. Byl vypracován dokument Hodnocení činnosti krajské organizace Svazu českých skladatelů v Brně v letech 1968 až 1969, který obsahoval analýzu činnosti a stanovisek ve svazové organizaci v krizových letech, tento dokument byl projednán a schválen na členském aktivu dne 9. ř́jna 1974. ${ }^{11}$

\footnotetext{
7 Hudební rozhledy, 1973, roč. 26, č. 8, s. 337-339.

8 Rozbor činnosti Svazu českých skladatelů a koncertních umělců, s. 2, ABO SČSKU, nečíslovaná složka, sign. DkCHK00000615.

9 Brněnský SČSKU v perspektivách. Opus musicum, 1974, roč. 6, č. 2, s. 42.

10 Hudební rozhledy, 1973, roč. 26, č. 12, s. 529.

11 Podklady pro referát na II. sjezdu Svazu českých skladatelů a koncertních umělců, ABO SČSKU, nečíslovaná složka.
} 
$\mathrm{Na}$ tomto místě mi dovolte se rozloučit provoláním výboru krajské organizace: „Nehovořilo se ovšem jen o minulosti. Dnes nám jde hlavně o to, abychom mohli odpovědně pracovat pro naplněni společenského poslání socialistické kulturní politiky. Proto výbor predložil členskému aktivu bohatý plán práce na sezónu 1974-1975. [...] V této sezóně chceme začit intenzivně propagovat a provádèt novou tvorbu našich soudobých skladatelů žijicich v jihomoravském kraji. [...] Budeme se snažit udržet tento stav i pro budoucnost zejména tím, že v nemenši míre využijeme kulturního zázemí v kraji pro oslaveni 30. výroči osvobození kulturními činy, hudebním uměním směrujicím $k$ životu. ${ }^{" 12}$

Silvie Adamová je studentkou doktorského programu oboru Hudební vědy na Filozofické fakultě Masarykovy univerzity v Brně, je zaměstnána jako referenční pracovník v Ústřední knihovně Filozofické fakulty a dále pracuje jako asistent produkce v Národním divadle Brno.

\begin{abstract}
:
This article deals with circumstances of formation of the Union of Czech composers and concert artists in Brno. It provides further information about the period between 1970 and 1974 during Union formation. It also explains how the musical periodicals captured the situation at that time. The research focuses mainly on the question of cultural and political development.
\end{abstract}

\title{
Key words:
}

Union of Czech composers and concert artists, concert artists, musicologists, political development after 1968

\section{Bibliography:}

Analýza činnosti a vývojových tendenci SČS od jeho IV. sjezdu (1967) do období likvidace (1971), uloženo v ODH MZM, Archiv brněnské pobočky SČS, nečíslovaná složka.

Brněnský SČSKU v perspektivách. Opus musicum, 1974, roč. 6, č. 2, s. 42.

FUKAČ, Jiří - VYSLOUŽIL, Jiří - MACEK, Petr (eds.). Slovnik české hudebni kultury. Praha: Editio Supraphon, 1997.

Hudebni rozhledy, 1973, roč. 26, č. 12.

KARAFIÁT, Jan. Brněnské jaro 1968. K činnosti brněnské odbočky Svazu československých skladatelu mezi 4. sjezdem a rozpadem SČS. Brno, 2011.

Memorandum ustavujícího valného shromáždění Svazu českých skladatelů. Hudební rozhledy, 1969 , roč. 22 , č. 6 , s. 163.

Podklady pro referát na II. sjezdu Svazu českých skladatelů a koncertních umělců, ABO SČSKU, nečíslovaná složka.

Rozbor činnosti Svazu českých skladateli̊ a koncertních umělců, s. 2, ABO SČSKU, nečíslovaná složka, sign. DkCHK00000615.

Stanovy Svazu českých skladatelů a koncertních umělců. Hudební rozhledy, 1973, roč. 26, č. 8, s. 337-339. 
Z činnosti SČSKU v Brně. Opus musicum, 1974, roč. 6, č. 10, s. 1.

Zpráva o průběhu mimořádného sjezdu Svazu čs. skladatelů. Hudební rozhledy, 1969, roč. 22, č. 6 , s. 162. 
